The AEsthetics OF hate 



\title{
THE AESTHETICS OF HATE
}

\author{
Far-Right Intellectuals, Antisemitism, and Gender in 1930s France
}

\section{SANDRINESANOS}

Stanford University Press - Stanford, California 
Stanford University Press

Stanford, California

(C) 2013 by the Board of Trustees of the Leland Stanford Junior University. All rights reserved.

This book has been published with the assistance of the Claudia Clark-Rebecca GershensonMegan McClintock Memorial Fund of the History Department of Rutgers, the State University of New Jersey-New Brunswick, and the Joe B. Frantz History Enhancement Fund at Texas A\&M University-Corpus Christi.

No part of this book may be reproduced or transmitted in any form or by any means, electronic or mechanical, including photocopying and recording, or in any information storage or retrieval system without the prior written permission of Stanford University Press.

Printed in the United States of America on acid-free, archival-quality paper

Library of Congress Cataloging-in-Publication Data

Sanos, Sandrine, author.

The aesthetics of hate : far-right intellectuals, antisemitism, and gender in 1930s France / Sandrine Sanos.

pages $\mathrm{cm}$

Includes bibliographical references and index.

ISBN 978-0-8047-7457-4 (cloth : alk. paper)

1. Right-wing extremists-France-History-2oth century. 2. Radicalism-France-History2oth century. 3. Antisemitism-France-History-2oth century. 4. Masculinity-FranceHistory-2oth century. 5. Fascist aesthetics-France-History-2oth century. 6. Politics and literature-France-History-2oth century. 7. France-Intellectual life-2oth century. 8. France-Politics and government-1914-1940. I. Title.

HN44O.R3S26 2012

303.48'40944-dc23

2012014036

Typeset by Bruce Lundquist in 10/14 Minion Pro 
$\grave{A}$ mes parents, Louise et Serge Sanos,

à qui je dois tout et sans qui rien n'aurait été possible. 
